Vol. 20(2011): 327-340.

\title{
Biosynthesis of very long chain polyunsaturated fatty acids in the leafy vegetable chicory
}

\author{
Hattem Mekky ${ }^{1}$, Maged Mohamed ${ }^{2}$, Colin Lazarus ${ }^{2}$, J. Brian Power ${ }^{1}$ and Michael R. Davey,,* \\ ${ }^{1}$ Plant and Crop Sciences Division, School of Biosciences, University of Nottingham, Sutton Bonington Campus, \\ Loughborough LE12 5RD, UK \\ ${ }^{2}$ School of Biological Sciences, University of Bristol, Woodland Road, Bristol \\ BS8 1UG, UK \\ *e-mail:mike.davey@nottingham.ac.uk
}

\begin{abstract}
The synthesis of very long chain polyunsaturated fatty acids (VLCPUFAs) was investigated in five cultivars of chicory. Genes for enzymes of the $\omega 3 / 6 \Delta^{8}$-desaturation biosynthetic pathways for the formation of $\mathrm{C} 20$ VLCPUFAs were inserted into chicory by Agrobacterium-mediated transformation of leaf explants. Plants were transformed by genes encoding $\Delta^{9}$-specific elongating activity from Isochrysis galbana, $\Delta^{8}$-desaturase from Euglena gracilis and $\Delta^{5}$-desaturase from Mortierella alpina, either separately or in combination; transgenic plants were selected on culture medium containing glufosinate ammonium for those transformed with the $\Delta^{9}$-elongase gene alone or in combination with the $\Delta^{8}$-desaturase gene, or kanamycin for plants transformed with the $\Delta^{5}$-desaturase gene. PCR showed the presence of the transgenes within the genome of selected plants, with RT-PCR confirming gene expression. Gas Chromatography of fatty acid methyl esters extracted from freeze-dried leaves of transgenic plants quantified the synthesis of omega- 6 arachidonic acid and its precursors eicosadienoic and dihomo- $\gamma$-linolenic acids, and omega- 3 eicosapentaenoic acid together with its precursors eicosatrienoic and eicosatetraenoic acids. This is the first report of the production of VLCPUFAs in a leafy vegetable. Since VLCPUFAs are the precursors of prostaglandins, the formation of prostaglandins was also investigated in chicory following a second transformation event using the PGHS-1 gene from Mus musculus.
\end{abstract}

Key words: Very long chain polyunsaturated fatty acids (VLCPUFAs), Agrobacterium-mediated transformation, $\Delta^{8}$-desaturation biosynthetic pathways, transgenic plants, Gas Chromatography (GC) 
Mekky, H. et al. Biosynthesis of VLCPUFAs in chicory

\section{Introduction}

Chicory, a leafy vegetable that is consumed both in the cooked and raw states, has several important health-related attributes. Meehye and Kyung (1996) recognised its antidiabetic properties, while aqueousmethanolic extracts of the seeds show a hepatoprotective activity due to esculetin, the latter being a major component of the plant (Gilani et al. 1998). Root extracts of chicory relieve liver ailments and haemorrhoids by reducing hepatic concentrations of lipids, triglycerides and cholesterol (Gupta et al. 1993). Extracts of chicory inhibit the growth of tumour cells through their content of the flavonoid quercetin (Hertog et al. 1992) and the sesquiterpene lactone 11 $\beta$, 13-dihydrolactucopicrin (Christope et al. 1996). Balbaa et al. (1973) examined the pharmacological properties of chicory extracts on hearts isolated from toads. Extracts had a quinidine-like action, verifying the use of such extracts against diseases characterized by tachycardia, arrhythmias and fibrillations, as indicated in folklore. Lactucin and its derivatives lactucopicrin and 11 $\beta, 13$-dihydrolactucin, which are characteristic bitter sesquiterpene lactones of chicory, showed analgesic activities more pronounced than those of ibuprofen, the latter being used as a standard (Wesołowska et al. 2006). Ethyl acetate extracts of chicory roots had a marked antiinflammatory activity by inhibiting prostaglandin $\mathrm{E}_{2}$ (Cavin et al. 2005), while 8-deoxylactucin had a similar effect by inhibiting DNA binding of the transcription factor NF- $\mathrm{kB}$ (Malarz et al. 2007). Polar extracts of chicory leaves also inhibited growth of the aerobic mesophilic bacteria, Leuconostoc mesentroides and Listeria monocytogenes (Pascual and Robledo 1998), water extracts had a similar effect on the growth of Agrobacterium tumefaciens, Erwinia carotovora, Pseudomonas fluorescens and $P$. aeruginosa (Petrovic et al. 2004), while two main sesquiterpene lactones, 8 -deoxylactucin and $11 \beta$, 13-dihydrolactucin, inhibited the growth of the fungus Trichophyton tonsurans var. sulfureum (Mares et al. 2005). Lactucin and lactucopicrin exhibited antimalarial properties against clone HB3 of the strain Honduras-1 of Plasmodium falciparum (Bischoff et al. 2004).
Increasing the medicinal importance of plants is a goal of pharmaceutical research (Malarz et al. 2005). VLCPUFAs that include arachidonic, eicosapentaenoic and docosahexaenoic acids are engaged in neonatal retinal and brain development, as well as cardiovascular health and disease prevention. Arachidonic and eicosapentaenoic acids are precursors of eicosanoids, including prostaglandins (Qi et al. 2004), in addition to maintaining cellular membranes through the regulation of cholesterol synthesis and its transport (Ani et al. 2003).

VLCPUFAs are synthesised in humans from linoleic acid (LA, C18:2 $\Delta^{9,12}$ ) and $\alpha$-linolenic acid (ALA, C18:3 $\Delta^{9,12,15}$ ) obtained from the diet, but their biosynthesis is limited and is regulated by dietary and hormonal changes. Consequently, VLCPUFAs are obtained mainly from oily fish. However, the consumption of such fish has declined recently, in addition to the reduction of fish stocks and possible contamination of fish oils by pollutants, such as heavy metals, polychlorinated biphenyls, dioxins and other chlorine-based compounds. Even fish farming requires considerable amounts of fish oils to optimize growth and nutrition of the farmed animals. Aquaculture exacerbates the problem (Napier 2006), rather than being a replacement for the diminishing natural reserves of marine fish. Napier et al. (2004) discussed the biosynthesis of health beneficial fatty acids in transgenic plants and the feasibility of synthesizing "Designer oils" in transgenic plants at concentrations equivalent to those found in marine organisms (Napier and Graham 2010). Venegas-Caleron et al. (2010) also reviewed progress in the metabolic engineering of oil-seed crops to synthesize fatty acids.

Improvement of seed oil quality has been achieved by transforming rice with a soybean microsomal omega-3-fatty acid desaturase gene. The latter encodes the microsomal omega-3-fatty acid desaturase enzyme, essential in the production of the $n-3$ polyunsaturated fatty acid, $\alpha$-linolenic acid. This approach resulted in a 10 fold increase in the concentration of $\alpha$-linolenic acid in rice seed oil (Ani et al. 2003). Jimenez et al. (2009) compared the profiles and relative concentrations of fatty acids in transgenic plants and isogenic lines of corn and soybean. More recently, Cheng et al. (2010) 
Vol. 20(2011): 327-340.

reported the biosynthesis of eicosapentaenoic acids in transgenic Brassica carinata. Other authors have isolated and characterized desaturases and elongases for fatty acid biosynthesis in microalgae (Petrie et al. 2010a), while Petrie et al. (2010b) isolated elongases which they expressed in Nicotiana benthamiana. Similarly, Taylor et al. (2009) reported seed-specific expression of nervonic acid in Arabidopsis thaliana and B. carinata using a gene for 3-ketoacyl-CoA synthase from Cardamine. The model plant, $A$. thaliana was also used as experimental material to assess the biosynthesis of omega-3-fatty acids, the plant being transformed sequentially with genes encoding a $\Delta^{9}$-specific elongating activity from Isochrysis galbana, a $\Delta^{8}$ desaturating activity from Euglena gracilis, and a $\Delta^{5}$-desaturating activity from Mortierella alpina. This strategy resulted in accumulation of arachidonic and eicosapentaenoic acids in transgenic plants (Qi et al. 2004). The current investigation was instigated to evaluate the feasibility, using a similar strategy, to express VLCPUFAs in leafy vegetables, chicory being chosen as the target plant because of the ease of transforming this crop.

\section{Materials and methods}

\section{Plant material and bacterial strains for transformation}

Five cvs. of chicory were used as target plants for transformation, namely Brussels Witloof, Pain du Sucre (E.W. King Ltd., Kelvedon, UK), Sponda da Taglio, Pan di Zucchero and Poncho (B and T World Seeds, Paguignan, France). The disarmed A. tumefaciens strain AGL1 carried a $\Delta^{9}$ elongase gene from Isochrysis galbana (pCB302.1; Qi et al. 2002), a $\Delta^{8}$ desaturase gene from Euglena gracilis (pBECKS19.6; Wallis and Browse, 1999), a $\Delta^{5}$ desaturase gene from Mortierella alpina (pCAMBIA23-EC- $\Delta^{5}$-desaturase), the $\Delta^{9}$ elongase + the $\Delta^{8}$ desaturase genes on the same vector (pCB302.3; Xiang et al. 1999), and the prostaglandin endoperoxidase gene (PGHS-1) from Mus musculus (pCAMBIA23-EC-PGHS-1). Figure 1 shows the maps of the different constructs used in this investigation.

\section{Preparation of leaf explants and Agro- bacterium - mediated transformation}

Seeds (achenes) were surface sterilised by immersion in 20\% (v/v) "Domestos" bleach solution (Unilever Ltd., Kingston-Upon-Thames, UK; 30 min), washed 3 times with sterile reverse osmosis water and blotted dry on sterile filter paper (No.1; Whatman, Maidstone, UK). Achenes (15 per $9 \mathrm{~cm}$ Petri dish) were placed on $25 \mathrm{ml}$ aliquots of Murashige and Skoog (1962), MS-based medium supplemented with $30 \mathrm{~g} \mathrm{l}^{-1}$ sucrose, and semi-solidified with $0.8 \%(\mathrm{w} / \mathrm{v})$ agar, $\mathrm{pH} 5.8$. Dishes were sealed with Nescofilm (Nippon Shoji Kaisha Ltd., Osaka, Japan) and incubated with a $16 \mathrm{~h}$ photoperiod $(50 \mu \mathrm{mol}$ $\mathrm{m}^{-2} \mathrm{sec}^{-1}$; "Daylight" fluorescent tubes; Sylvania, Germany) at $23 \pm 1{ }^{\circ} \mathrm{C}$.

Leaves and cotyledons were excised from $14 \mathrm{~d}$ old seedlings and scored on their abaxial surfaces. Explants were immersed (5 min) in an overnight culture of Agrobacterium $\left(\mathrm{OD}_{600}=0.6\right)$ diluted 1:1 $(\mathrm{v}: \mathrm{v})$ with liquid MS-based medium lacking growth regulators, before blotting on sterile filter paper. Inoculated explants were cultured for $3 \mathrm{~d}$ on $25 \mathrm{ml}$ aliquots of MS-based shoot regeneration medium containing $1.0 \mathrm{mg} \mathrm{l}^{-1}$ benzylaminopurine (BAP), $0.1 \mathrm{mg} \mathrm{l}^{-1}$ indole-3-yl acetic acid (IAA), $30 \mathrm{~g} \mathrm{l}^{-1}$ sucrose, and semi-solidified with $0.8 \%(\mathrm{w} / \mathrm{v})$ agar (Sigma-Aldrich), pH 5.8, in $9 \mathrm{~cm}$ diameter Petri dishes. Dishes were sealed with Nescofilm.

After $3 \mathrm{~d}$ of co-cultivation in the dark at $23 \pm$ $1^{\circ} \mathrm{C}$, explants were transferred to semi-solid MSbased shoot regeneration medium supplemented with $400 \mathrm{mg} \mathrm{l}^{-1}$ cefotaxime and $400 \mathrm{mg} \mathrm{l}^{-1}$ vancomycin to eliminate Agrobacteria, with inclusion of glufosinate ammonium $\left(5 \mathrm{mg} \mathrm{l}^{-1}\right)$ in the medium following inoculation of explants with Agrobacterium carrying $\Delta^{9}$ or $\Delta^{9}+\Delta^{8}$ genes, or kanamycin sulphate $\left(50 \mathrm{mgl}^{-1}\right)$ with the $\Delta^{5}$ or $\Delta^{8}$ genes. Inoculated explants were transferred to the surface of new medium containing the same concentrations 


\section{AGRICULTURAL AND FOOD SCIENCE}

Mekky, H. et al. Biosynthesis of VLCPUFAs in chicory

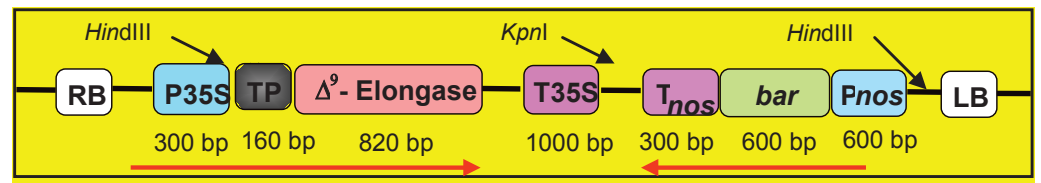

pCB302.1- $\Delta^{9}$-elongase

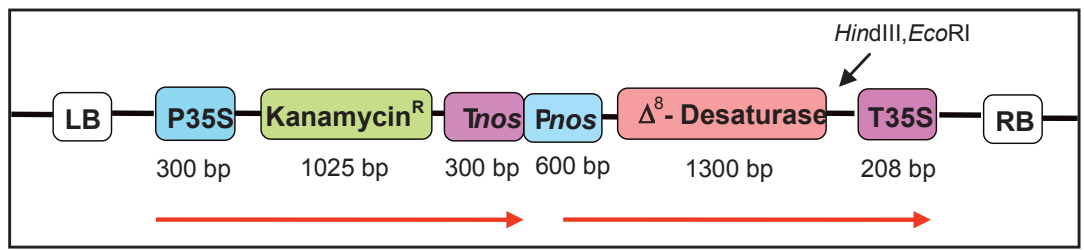

pBECKS- $\Delta^{8}$-desaturase

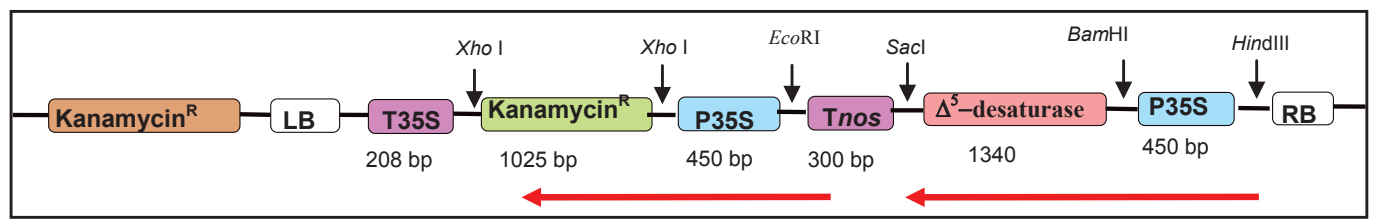

pCAMBIA-23-EC- $\Delta \Delta^{5}$-desaturase

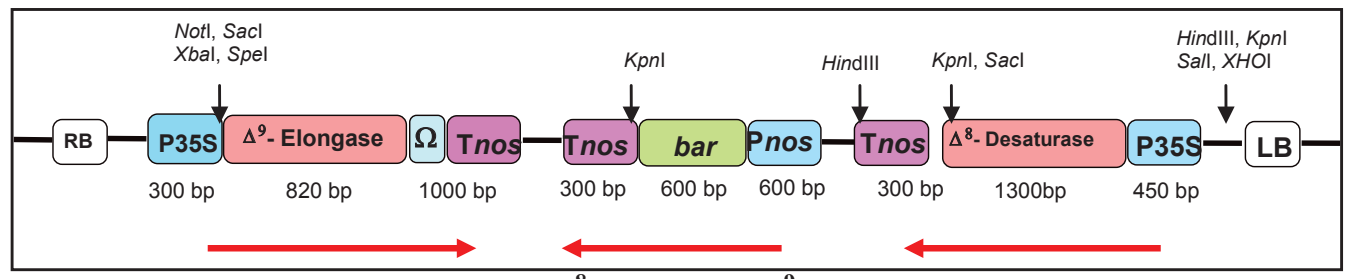

pCB302.3 $\Delta^{8}$-desaturase $\Delta^{9}$-elongase

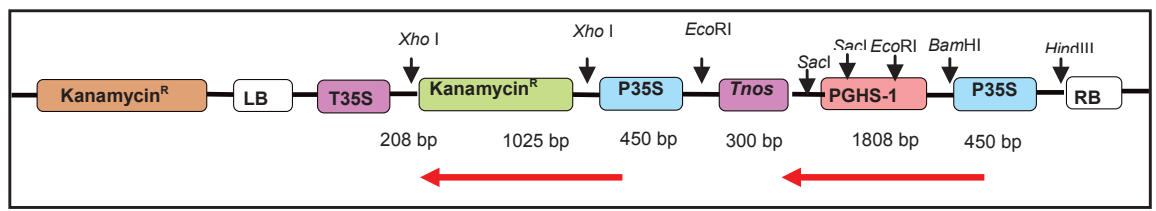

pCAMBIA-23-EC-PGHS-1

P35S: Cauliflower Mosaic Virus 35S promoter, Pnos: Nopaline synthase promoter, TP: transit peptidase

Tnos: Nopaline synthase terminator, bar: BASTA (Glufosinate ammonium) resistance

Fig. 1. T-DNA map of pCB302.1- $\Delta^{9}$ elongase, pBECKS- $\Delta^{8}$ desaturase, pCAMBIA-23-EC- $\Delta^{5}$ desaturase, and pCAMBIA-23-EC-PGHS-1 in Agrobacterium strain AGL1, showing the direction of transcription of the selectable marker genes ( $b a r$ for resistance to glufosinate ammonium; kanamycin ${ }^{\mathrm{R}}$ [nptII] for resistance to kanamycin) and the genes of interest, $\Delta^{9}$ elongase, $\Delta^{8}$ desaturase, $\Delta^{5}$ desaturase and PGHS-1, located between the T-DNA left and right borders. 
Vol. 20(2011): 327-340.

of antibiotics every $14 \mathrm{~d}$ for $28-42 \mathrm{~d}$, until regenerated shoots each attained a height of $2-3 \mathrm{~cm}$. Shoots excised from the parent tissues, were rooted on the same medium as used for selection, but with $0.1 \mathrm{mg} \mathrm{l}^{-1}$ indole-3-butyric acid (IBA) replacing BAP and IAA. Putatively transformed plants were established in Levington M3 compost (Scotts UK Professional, Ipswich, UK) under glasshouse conditions and grown to maturity for assessments of achene production. Controls involved the culture of uninoculated explants on medium lacking or containing selection agents. Non-transformed plants were grown in the glasshouse alongside transgenic plants. In experiments with the $\Delta^{5}$ and PGHS-1 genes, plants transformed with the $\Delta^{9}+\Delta^{8}$ genes and selected using glufosinate ammonium, were subjected to a second transformation with the $\Delta^{5}$ or PGHS-1 genes using leaf explants as target tissues. Double transformants were selected on medium containing kanamycin sulphate $\left(50 \mathrm{mg} \mathrm{l}^{-1}\right)$.

\section{Plant DNA extraction}

Plant DNA was extracted from leaf tissues for PCR-analysis using a Gen Elute ${ }^{\mathrm{TM}}$ Plant Genomic DNA Miniprep Kit (Sigma-Aldrich), following the manufacturer's protocol.

\section{Polymerase chain reaction (PCR) analysis}

Putatively transformed plants were screened by PCR for the presence of the $\Delta^{9}$-elongase, the $\Delta^{8}$ desaturase, the $\Delta^{5}$-desaturase and the PGHS-1 genes. The $20 \mathrm{bp}$ oligonucleotide primers used to amplify coding regions were $5^{\prime}$-gggcgtatggatcttcatgt- $3^{\prime}$ and 5'-gcaggggacgttgatgtagt-3' ( $\Delta^{9}$-elongase, $175 \mathrm{bp}$ ), $5^{\prime}$-tggagtgctgggttatttcc-3' and $5^{\prime}$-ttgcagaccattgccaaata-3' ( $\Delta^{8}$-desaturase, $\left.178 \mathrm{bp}\right), 5^{\prime}$-atcaagcccaaccaaaagtg- $3^{\prime}$ and $5^{\prime}$-agtcgagatggggttgacac-3' $\left(\Delta^{5}\right.$ desaturase, $159 \mathrm{bp})$ and $5^{\prime}$-cagtgcctcaaccccatagt-3' and 5' -gtggctatttcetgcagctc-3' (PGHS-1). PCR was performed using approx. $100 \mathrm{ng}$ of purified genomic DNA and Taq polymerase (ABgene, Epsom, UK).
The reaction conditions were 10 min denaturation at $94{ }^{\circ} \mathrm{C}, 35$ cycles each of $1 \mathrm{~min}$ at $94{ }^{\circ} \mathrm{C}, 1 \mathrm{~min}$ at $\mathrm{X}{ }^{\circ} \mathrm{C}$ and $1 \mathrm{~min}$ at $72^{\circ} \mathrm{C}$, where $\mathrm{X}=57.3$ for the $\Delta^{9}$-elongase gene, 55.3 for both the $\Delta^{8}$-desaturase and the $\Delta^{5}$-desaturase genes, and 59.4 for the PGHS-1 gene. DNA from non-transformed (control) plants was included in the experiments. Amplified products were separated by electrophoresis on $1.5 \%(\mathrm{w} / \mathrm{v})$ agarose gels and visualized under UV illumination following staining with ethidium bromide (Sambrook et al. 1989).

\section{RNA extraction for reverse transcriptase (RT) PCR-analysis}

Young leaf material (100 mg) was harvested from putatively transgenic and non-transformed plants. Samples, in axenic $1.5 \mathrm{ml}$ microfuge tubes, were flash frozen in liquid nitrogen, ground to a fine powder and processed using an RNeasy Plant Mini Kit (Qiagen Ltd., Crawley, UK). RNA samples were treated with RNase-free DNase (Promega, Southampton, UK) according to the manufacturer's instructions. Aliquots of $40 \mathrm{ng}$ RNA template, $1 \mu \mathrm{M}$ oligo-dT primer and $11 \mu \mathrm{R}$ Rase-free water were placed in $0.5 \mathrm{ml}$ thin walled microfuge tubes. After incubation at $70{ }^{\circ} \mathrm{C}(5 \mathrm{~min}), 2 \mu \mathrm{l} 10 \mathrm{X}$ synthesis buffer, $2 \mu \mathrm{dNTP} \operatorname{mix}(0.5 \mathrm{mM}$ each dNTP) and $1 \mu \mathrm{l}$ Sensiscript Reverse Transcriptase (Qiagen) were added. Tubes were incubated at $37{ }^{\circ} \mathrm{C}$ (60 min). A Sensiscript Reverse Transcriptase First Strand Synthesis Kit (Qiagen) was used with PCR amplification.

\section{Gas Chromatography for identification of VLCPUFAs}

Fatty acids were extracted as fatty acid methyl esters (FAMEs) from leaf tissues of glasshouse-grown plants (during the flowering stage) according to Browse et al. (1986). GC analysis was conducted by injecting $2-8 \mu \mathrm{l}$ of the hexane extract into a Hewlett Packard 5880A Series gas chromatograph 
Mekky, H. et al. Biosynthesis of VLCPUFAs in chicory

equipped with a $0.25 \mathrm{~mm} \times 30 \mathrm{~m}, 0.25 \mu \mathrm{m}$ RSL-500 BP bonded capillary column and a flame ionization detector (Schimadzu UK Ltd, Milton Keynes, UK). Fatty acids were identified by comparison with retention times of FAMEs standards (SigmaAldrich). Relative percentages of the fatty acids were estimated from peak areas.

\section{Statistics}

Mean and standard deviations were calculated for all quantitative data. A one-way analysis of variance (ANOVA) was performed to test the consistency of results within a chicory cv. (ANOVA: Within Groups Design) and to test the influence of the expressed transgenes on the different cvs. (ANOVA: Between Groups Design).

\section{Enzyme immunoassay (EIA) for quantifi- cation of prostaglandins}

Aliquots (100 mg) of freeze-dried plant tissue were

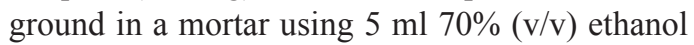
and the homogenate was incubated for $15 \mathrm{~min}$ at 4 ${ }^{\circ} \mathrm{C}$. The homogenate was centrifuged (13000 rpm, MSE Centaur 2; Fisons, Loughborough, UK), the supernatant retained and the alcohol removed from the supernatant by evaporation under reduced pressure. The remaining aqueous solution was adjusted to $\mathrm{pH} 4.0$ using dilute $\mathrm{HCl}$, passed through an activated $\mathrm{C}-18$ solid phase extraction column (Cayman Chemical Co., Ann Arbor, USA). The column was rinsed with $5 \mu$ ultra-pure water followed by $5 \mu 1$ of HPLC-grade hexane (Fisher Scientific, Loughborough, UK). The column was eluted with $5 \mu 1$ HPLC-grade ethyl acetate containing $1 \%$ (v/v) HPLC-grade methanol (Fisher Scientific). Ethyl acetate was evaporated under reduced pressure, and the residue dissolved in $500 \mu 1$ enzyme immunoassay (EIA) buffer for enzyme immunoassay analysis. Prostaglandin $\mathrm{H}$ was assayed with a prostaglandin EIA screening kit (Cayman Chemical Co.) using the manufacturer's protocol.

\section{Results}

\section{Shoot regeneration from leaf explants}

Shoots regenerated from callus produced at the margins and scored areas of all leaf explants cultured on MS-based medium with $1 \mathrm{mg} \mathrm{l}^{-1}$ BAP, $0.1 \mathrm{mg}$ $\mathrm{l}^{-1}$ IAA, $30 \mathrm{~g} \mathrm{l}^{-1}$ sucrose and semi-solidified with $0.8 \%(\mathrm{w} / \mathrm{v})$ agar, after $28 \mathrm{~d}$ of culture. Regenerated shoots developed adventitious roots within $48 \mathrm{~h}$ after transfer to semi-solid MS-based culture medium supplemented with $0.1 \mathrm{mg} \mathrm{l}^{-1}$ IBA. Callus formation and shoot regeneration were inhibited on explants not inoculated with $A$. tumefaciens when the explants were cultured on MS-based shoot regeneration medium containing $50 \mathrm{mg} \mathrm{l}^{-1}$ kanamycin sulphate, or glufosinate ammonium $\left(5 \mathrm{mgl}^{-1}\right)$ as selection agents. In contrast, $80 \pm 5 \%, 78 \pm 5 \%, 75$ $\pm 5 \%, 75 \pm 5 \%$ and $70 \pm 5 \%$ of Agrobacteriuminoculated leaf explants formed callus on selection medium irrespective of the selection agent for the cvs. Brussels Witloof, Pain du Sucre, Pan di Zucchero, Poncho and Sponda da Taglio, respectively. Shoots regenerated within 2 months of the culture of explants on selection medium containing kanamycin or glufosinate ammonium (Figure 2A, B).

Adventitious roots developed on $65 \pm 5 \%$ of the shoots regenerated from inoculated and uninoculated leaf explants of all of the 5 chicory cvs. following excision of shoots from the parent callus and transfer to medium in screw-capped glass jars (Figure 2C). Ninety $\pm 5 \%$ of the rooted regenerated plants that were resistant to the selection agents, and control (non-transformed) plants from all cvs., survived transfer to compost. Plants regenerated from Agrobacterium-inoculated explants were morphologically identical to plants regenerated from uninoculated explants (Figure 2D). 


\section{AGRICULTURAL AND FOOD SCIENCE}

Vol. 20(2011): 327-340.
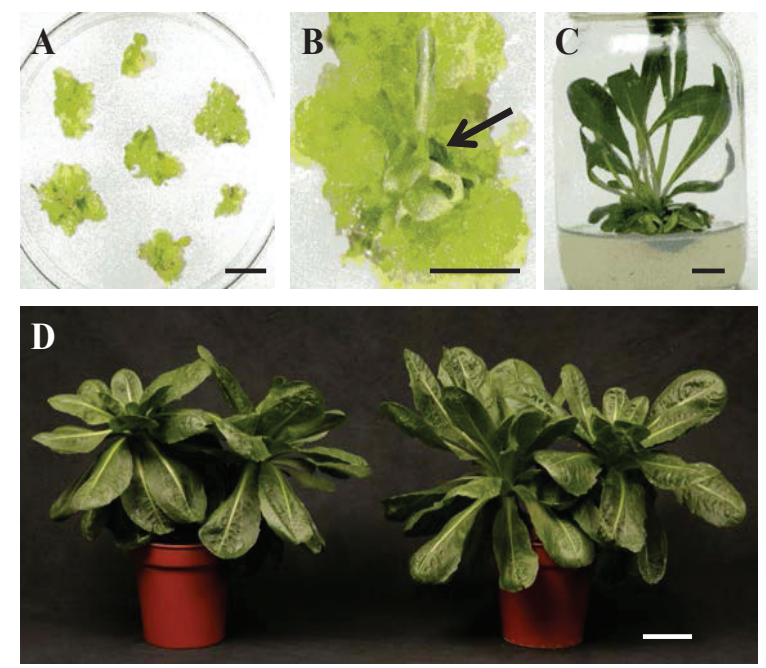

Fig. 2A, B. Callus formation (A) and subsequent shoot regeneration, arrowed, (B) from leaf explants of the cv. Brussels Witloof following inoculation with $A$. tumefaciens carrying the $\Delta^{9}+\Delta^{8}$ genes and culture for 28 days on MS-based medium supplemented with $1.0 \mathrm{mg} \mathrm{l}^{-1}$ BAP, $0.1 \mathrm{mg} \mathrm{l}^{-1}$ IAA and 5.0 $\mathrm{mg} \mathrm{l}^{-1}$ glufosinate ammonium as selection agent. Fig. 2C. A regenerated shoot transferred to MSbased medium containing $0.1 \mathrm{mg} \mathrm{l}^{-1}$ IBA to induce root development.

Fig. 2D. A plant of Brussels Witloof regenerated from a leaf explant inoculated with $A$. tumefaciens carrying the $\Delta^{9}+\Delta^{8}$ genes (left), which is morphologically identical to its non-transformed counterpart (right).

Bars $=1 \mathrm{~cm}-\mathrm{A}, \mathrm{B}, \mathrm{C} ; 6 \mathrm{~cm}-\mathrm{D}$.

\section{PCR analysis}

DNA fragments of $175 \mathrm{bp}, 178 \mathrm{bp}, 159 \mathrm{bp}$ and $209 \mathrm{bp}$ (Figure 3A-D) corresponding to the coding regions of $\Delta^{9}, \Delta^{8}, \Delta^{5}$ and PGHS-1 genes, respectively, were detected by PCR in selected, putatively transformed plants established in the glasshouse.
A

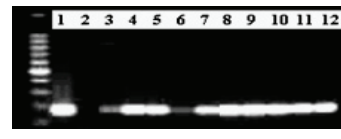

C

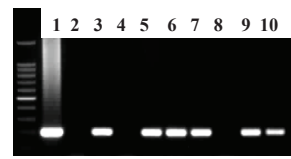

B

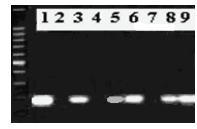

D

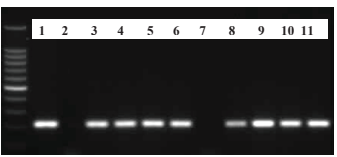

Fig. 3A. Amplification of the $\Delta^{9}$ elongase gene in leaf DNA extracts of selected plants of cv. Brussels Witloof. Lane $1=$ plasmid; lane $2=$ wild type plant; lanes 3-7 = plants transformed with $\Delta^{9}+\Delta^{8}, \Delta^{5}$ genes; lanes 8-12= plants transformed with $\Delta^{9}+\Delta^{8}$ genes.

Fig. 3B. Amplification of the $\Delta^{8}$ desaturase gene in leaf DNA extracts of representative kanamycin-resistant plants. Lane 1 = plasmid; lanes 2, 4 and 7 = wild type plants of cvs. Sponda da Taglio, Pain du Sucre and Brussels Witloof, respectively; lanes 3, 5, 6, 8 and $9=$ plants transformed with the $\Delta^{8}$ gene in the previously stated cvs.

Fig. 3C. Amplification of the $\Delta^{5}$ gene in leaf DNA extracts of kanamycin-resistant plants. Lane $1=$ plasmid; lanes 2 and 8 = wild type plants of cvs. Brussels Witloof and Sponda da Taglio, respectively; lanes 3 and 5-7 = transformed plants of the cv. Brussels Witloof; lanes 9 and $10=$ transformed plants of cv. Sponda da Taglio.

Fig. 3D. Amplification of PGHS-1 gene in leaf DNA extracts of glufosinate ammonium/kanamycin-resistant plants transformed with the $\Delta^{9}+\Delta^{8}$ genes followed by the PGHS-1 gene. Lane $=1$ plasmid; lanes 2 and $7=$ wild type plants of cvs. Brussels Witloof and Sponda da Taglio, respectively. Lanes 3-6 and 8-11 = plants of Brussels Witloof and Sponda da Taglio transformed with the $\Delta^{9}+\Delta^{8}$ and PGHS-1 genes. 
Mekky, H. et al. Biosynthesis of VLCPUFAs in chicory

RT-PCR analysis using total RNA extracted from fully expanded young leaves excised from PCRpositive plants, confirmed the expression of the $\Delta^{9}$, $\Delta^{8}, \Delta^{5}$ and PGSH-1 genes in these randomly selected plants (Figure 4), although several of the plants that were PCR positive were RT-PCR negative (Table 1). Forty six plants, as confirmed by RT-PCR, expressed the $\Delta^{9}+\Delta^{8}$ genes, with the majority of these being of the cv. Brussels Witloof (15), followed by Pan di Zucherro (13), Poncho (10), Sponda da Taglio (6) and Pain du Sucre (2). Thirty eight plants expressed the $\Delta^{9}$ gene alone, with most being Poncho (16), Pan di Zucherro (13), Sponda da Taglio (6), Brussels Witloof (4) and Pain du Sucre (3). Plants transformed with the $\Delta^{5}$ and $\Delta^{8}$ genes alone were RT-PCR negative. Seven plants of Brussels Witloof, 3 of Sponda da Taglio, 2 of Pan di Zucherro and 2 of Poncho expressed the $\Delta^{9}+\Delta^{8}$ and $\Delta^{5}$ genes in combination following double transformation; 8 plants of Brussels Witloof and 4 of Sponda da Taglio expressed the PGHS- 1 alongside the $\Delta^{9}+\Delta^{8}$ genes. Double transformants were not recovered in Pain du Sucre, Pain du Zucherro and Poncho. As expected, PCR and RT-PCR analyses were negative using total RNA extracted from non-transformed plants.

Fig. 4. RT-PCR assay of total leaf mRNA of selected PCR positive plants transformed with the $\Delta^{9}$ gene and the $\Delta^{9}+\Delta^{8}$ genes of cv. Brussels Witloof. Lanes 1 and 2 = plasmid and wild type plant, respectively; lane $3=$ a plant transformed with the $\Delta^{9}$ gene; lanes 4-9 = plants transformed with the $\Delta^{9}+\Delta^{8}$ genes, those in lanes 6,8 and 9 are RT-PCR positive.

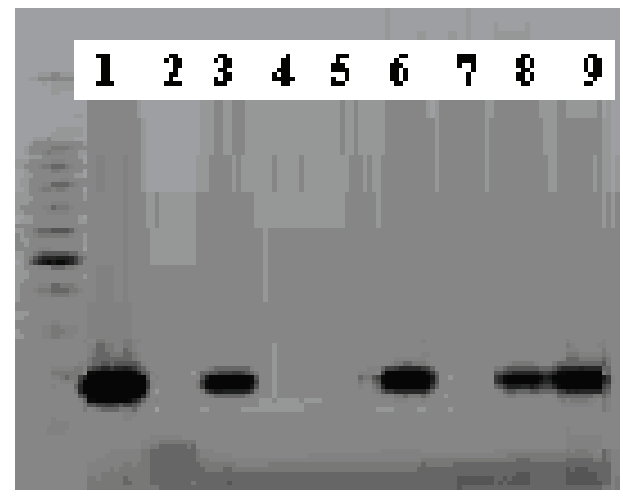

Table 1: The number of PCR positive, PCR negative and RT-PCR positive plants regenerated from Agrobacterium-inoculation of chicory cultivars.

\begin{tabular}{llllll}
\hline Genes & Brussels & Pain & Pain & Poucho & Sponda \\
& Witloof & du Sucre & di Zucherro & & da Taglio \\
\hline$\Delta^{9}$ & $8,7,4$ & $8,11,3$ & $17,25,13$ & $20,23,16$ & $6,15,6$ \\
$\Delta^{9}+\Delta^{8}$ & $22,6,15$ & $9,5,2$ & $14,5,13$ & $18,6,10$ & $9,10,6$ \\
$\Delta^{8}$ & $13,15,0$ & $8,11,0$ & $3,6,0$ & $3,9,0$ & $6,9,0$ \\
$\Delta^{5}$ & $15,23,0$ & $5,9,0$ & $10,19,0$ & $9,16,0$ & $5,11,0$ \\
$\Delta^{9}+\Delta^{8}+\Delta^{5}$ & $11,14,0$ & - & $4,0,0$ & $5,0,0$ & $2,7,0$ \\
$\Delta^{9}+\Delta^{8}, \Delta^{5}$ & $7,0,7$ & - & $2,0,2$ & $2,0,2$ & $3,0,3$ \\
$\Delta^{9}+\Delta^{8}$, PGHS-1 & $8,0,8$ & - & - & - & $4,0,4$ \\
\hline
\end{tabular}

Numbers, reading left to right, represent, PCR positive, PCR negative and RT-PCR positive plants, respectively. 


\section{GC analysis}

Freeze dried leaves from PCR and RT-PCR positive plants were analysed to confirm gene expression and the biosynthesis of fatty acids (Table 2). The construct pCB302.3 with the $\Delta^{9}+\Delta^{8}$ genes was expressed optimally in tested plants, followed by the $\Delta^{9}$ gene from pCB302.1. Additionally, when plants carrying the $\Delta^{9}+\Delta^{8}$ genes were transformed with the $\Delta^{5}$ desaturase gene (pCAMBIA-23), this resulted in the production of arachidonic and eicosapentaenoic acids in the transgenic plants (Figure 5).

Fig. 5. GC profile of chicory leaf fatty acid methyl esters in cv. Pan di Zucchero. Fatty acids were extracted from a non-transformed plant (A), and transgenic plants expressing the $\Delta^{9}$ gene (B), a transgenic plant with the $\Delta^{9}+\Delta^{8}$ genes $(\mathrm{C})$, and the $\Delta^{9}+\Delta^{8}$, plus $\Delta^{5}$ genes (D). $1=$ Linoleic acid (LA, C18:2 $\Delta^{9,12}$ ), $2=\alpha$ - Linolenic acid (ALA, C18:3 $\left.\Delta^{9,12,15}\right), 3=$ Eicosadienoic acid (EDA, C20:2 $\Delta^{11,14)}, 4=$ Eicosatrienoic acid (ETrA, C20:3 $\Delta^{11,14,17)}, 5=$ Dihomo- $\gamma$ linolenic acid (DGLA, C20:3 $\Delta^{8,11,14}$ ), $6=$ Eicosatetraenoic acid (ETA C20:4 $\Delta^{8,11,14,17}$ ), $7=$ Arachidonic acid (AAC20:4 $\left.\Delta^{5,8,11,14}\right), 8=$ Eicosapentaenoic acid (EPA C20:5 $\left.\Delta^{5,8,11,14,17}\right)$.

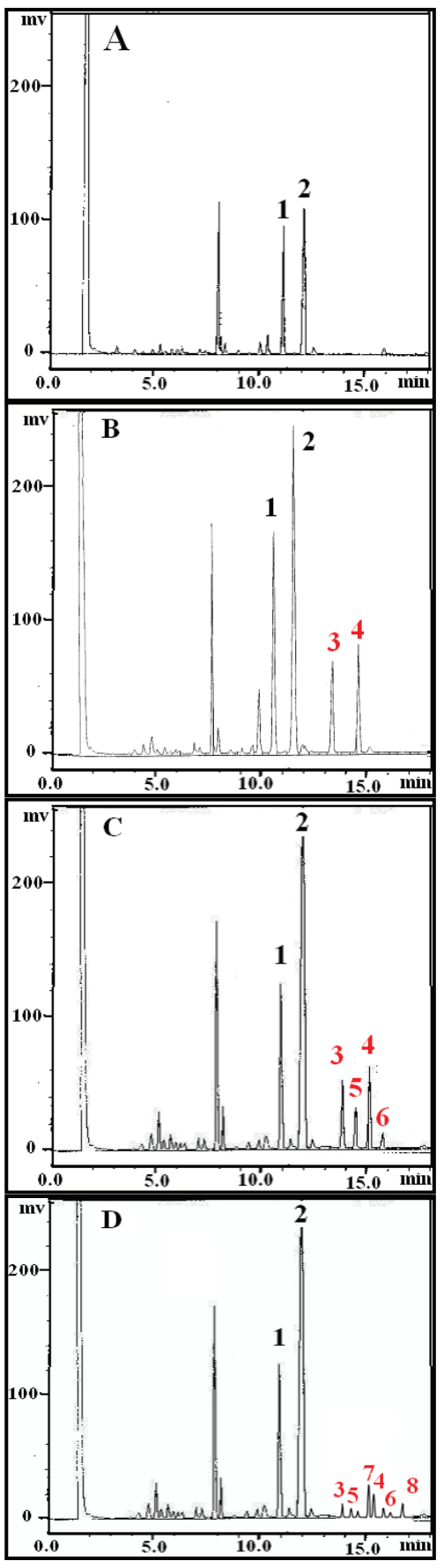




\section{AGRICULTURAL AND FOOD SCIENCE}

\section{Mekky, H. et al. Biosynthesis of VLCPUFAs in chicory}

Table 2: VLCPUFAs in representative examples of plants of different chicory cvs. expressing the $\Delta^{9}$ elongase gene, the $\Delta^{9}$ elongase $+\Delta^{8}$ desaturase genes, and the $\Delta^{9}$ elongase $+\Delta^{8}$ desaturase with the $\Delta^{5}$ desaturase genes.

\begin{tabular}{|c|c|c|c|c|c|c|c|c|c|c|c|}
\hline \multirow[b]{3}{*}{ Plant } & \multicolumn{8}{|c|}{ Mol \% of Fatty Acids } & \multicolumn{3}{|c|}{$\begin{array}{c}\text { Total } 20 \text { C Fatty } \\
\text { Acids }\end{array}$} \\
\hline & \multicolumn{4}{|c|}{$\omega 6$} & \multicolumn{4}{|c|}{$\omega 3$} & \multirow[b]{2}{*}{$\omega 6$} & \multirow[b]{2}{*}{$\omega 3$} & \multirow[b]{2}{*}{ Total } \\
\hline & $\begin{array}{l}\text { Linoleic } \\
\text { acid } \\
\text { 18:02 } \\
\text { Substrat } \\
\text { e }\end{array}$ & $\begin{array}{c}\text { Eicosa- } \\
\text { dienoic } \\
\text { acid } \\
20: 02 \\
\Delta^{9}\end{array}$ & $\begin{array}{c}\text { Dihomo- } \\
\gamma- \\
\text { linoleic } \\
\text { acid } \\
20: 03 \\
\Delta^{9}+\Delta^{8}\end{array}$ & $\begin{array}{c}\text { Arachidonic } \\
\text { acid } \\
20: 04 \\
\Delta^{9}+\Delta^{8}, \Delta^{5}\end{array}$ & $\begin{array}{c}\alpha- \\
\text { linolenic } \\
\text { acid } \\
18: 03 \\
\text { Substrate }\end{array}$ & $\begin{array}{c}\text { Eicosa- } \\
\text { trienoic } \\
\text { acid } \\
20: 03 \\
\Delta^{9}\end{array}$ & $\begin{array}{c}\text { Eicosa- } \\
\text { tetraenoic } \\
\text { acid } \\
20: 04 \\
\Delta^{9}+\Delta^{8}\end{array}$ & $\begin{array}{c}\text { Eicosa- } \\
\text { pentaenoic } \\
\text { acid } \\
20: 05 \\
\Delta^{9}+\Delta^{8}, \Delta^{5}\end{array}$ & & & \\
\hline $\mathrm{B} 2508$ & 6.00 & 1.59 & 7.35 & 1.07 & 13.65 & 1.08 & 5.07 & 7.00 & 10.0 & 13.1 & 23.2 \\
\hline $\mathrm{B} 2511$ & 5.00 & 0.16 & 4.97 & 0.27 & 15.92 & 0.18 & 1.01 & 4.43 & 5.4 & 5.6 & 11.0 \\
\hline S2601 & 1.00 & 0.35 & 1.00 & 1.44 & 4.59 & 0.17 & 4.94 & 1.70 & 2.8 & 6.8 & 9.6 \\
\hline S2605 & 10.00 & 6.98 & 1.38 & 0.28 & 6.55 & 0.20 & 0.65 & 3.50 & 8.6 & 4.4 & 13.0 \\
\hline B205 & 8.48 & 6.54 & 7.45 & 0.00 & 35.06 & 10.64 & 3.06 & 0.00 & 14.0 & 13.7 & 27.7 \\
\hline B233 & 10.05 & 6.50 & 10.44 & 0.00 & 36.21 & 9.80 & 2.85 & 0.00 & 16.9 & 12.7 & 29.6 \\
\hline $\mathrm{Pa} 601$ & 13.19 & 3.78 & 3.12 & 0.00 & 51.15 & 4.95 & 1.08 & 0.00 & 6.9 & 6 & 12.9 \\
\hline $\mathrm{Pa} 602$ & 11.53 & 3.85 & 2.54 & 0.00 & 52.74 & 5.52 & 1.18 & 0.00 & 6.4 & 6.7 & 13.1 \\
\hline Po1305 & 11.35 & 2.12 & 1.11 & 0.00 & 58.96 & 6.00 & 0.54 & 0.00 & 3.2 & 6.5 & 9.8 \\
\hline Po1307 & 9.67 & 2.15 & 1.60 & 0.00 & 52.01 & 3.43 & 1.38 & 0.00 & 3.8 & 4.8 & 8.6 \\
\hline $\mathrm{Pa} 140$ & 14.01 & 11.76 & 0.00 & 0.00 & 42.66 & 12.60 & 0.00 & 0.00 & 11.8 & 12.6 & 24.4 \\
\hline $\mathrm{Pa} 153$ & 12.94 & 7.32 & 0.00 & 0.00 & 51.41 & 13.52 & 0.00 & 0.00 & 7.3 & 13.5 & 20.8 \\
\hline Po745 & 19.84 & 5.15 & 0.00 & 0.00 & 34.34 & 3.09 & 0.00 & 0.00 & 5.2 & 3.1 & 8.2 \\
\hline Po749 & 27.72 & 3.02 & 0.00 & 0.00 & 46.02 & 1.72 & 0.00 & 0.00 & 3.0 & 1.7 & 4.7 \\
\hline $\mathrm{S} 1701$ & 18.19 & 5.86 & 0.00 & 0.00 & 43.42 & 8.66 & 0.00 & 0.00 & 5.9 & 8.7 & 14.5 \\
\hline $\mathrm{S} 1705$ & 13.84 & 4.49 & 0.00 & 0.00 & 46.25 & 10.27 & 0.00 & 0.00 & 4.5 & 10.3 & 14.8 \\
\hline
\end{tabular}

Cn: $\mathrm{m}$ n= carbon chain number, $\mathrm{m}=$ number of double bonds.

B2508, B2511 - $\Delta^{9}+\Delta^{8}, \Delta^{5}$ cv. Brussels Witloof.

S2601, S2605 - $\Delta^{9}+\Delta^{8}, \Delta^{5}$ cv. Sponda da Taglio.

B205, B233, $-\Delta^{9}+\Delta^{8}$ cv. Brussels Witloof.

Pa601, Pa602 $-\Delta^{9}+\Delta^{8}$ cv. Pan di Zucchero.

Po1305, Po1307 $-\Delta^{9}+\Delta^{8}$ cv. Poncho.

Pa140, Pa153 - $\Delta^{9}$ cv. Pan di Zucchero.

Po745, Po749 - $\Delta^{9}$ cv. Poncho.

S1701, S1705 - $\Delta^{9}$ cv. Sponda da Taglio. 
Vol. 20(2011): 327-340.

\section{Seed production}

There was considerable variation not only in the number of achenes produced by transgenic plants compared to non-transformed plants, but also between the non-transformed plants themselves ( $\mathrm{n}=$ 3 , throughout). For example, the number of achenes ranged from 612 in the non-transformed cv. Poncho to 27 in Sponda da Taglio. Brussels Witloof, Pain du Sucre and Pain di Zucherro set 24, 38 and 27 achenes, respectively. Some plants transformed with the $\Delta^{9}$ gene produced achenes comparable in number to their non-transformed counterparts, namely transformed plants of Pain du Sucre (30) and Pain di Zucherro (30). Other transgenic cvs. produced less achenes compared to non-transformed plants, as in Poncho (47) and Sponda da Taglio (1) and plants transformed with the $\Delta^{9}+\Delta^{8}$ genes [Poncho (9), Pain di Zucherro (2) and Pain du Sucre (5)]. Brussels Witloof and Sponda da Taglio carrying the $\Delta^{9}$ $+\Delta^{8}$ genes failed to set achenes.

\section{Enzyme immune assay (EIA)}

EIA performed on PCR-positive freeze-dried leaves of 4 plants of the cv. Brussels Witloof using a prostaglandin EIA screening kit confirmed expression of the PGHS-1 gene with significant accumulation $(p<0.0004)$ of prostaglandin when compared with four wild-type (control) plants. Table 3 and Figure 6 show the concentrations of prostaglandins in transformed plants of the cv. Brussels Witloof.

Table 3: Prostaglandin concentration in plants of the cv. Brussels Witloof expressing the PGHS-1 gene.

\begin{tabular}{lcc}
\hline Plant & $\begin{array}{l}\text { Prostaglandins } \\
\text { pg 100 mg } \\
\text { freeze-dried leaf } \\
\text { tissue }\end{array}$ & $\begin{array}{l}\text { Control pg } \\
100 \mathrm{mg}^{-1} \\
\text { freeze-dried } \\
\text { leaf tissue }\end{array}$ \\
\hline B2701 & 945.28 & 253.78 \\
B2704 & 719.99 & 332.04 \\
B2707 & 758.22 & 259.85 \\
B2708 & 643.93 & 311.21 \\
Mean & 766.85 & 289.22 \\
\hline
\end{tabular}

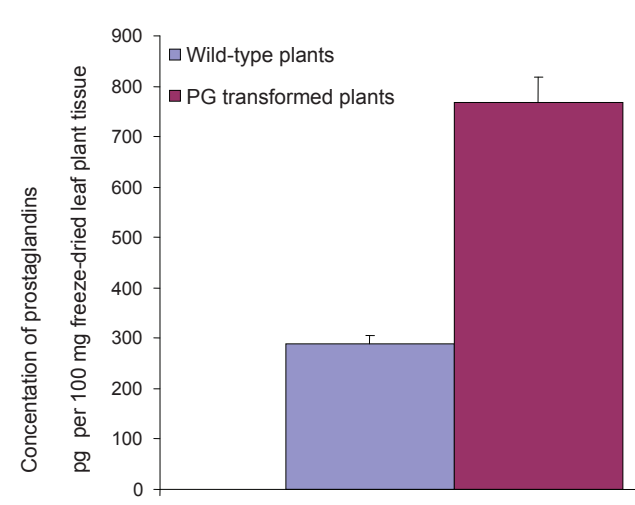

Fig. 6. Mean prostaglandin concentration in transgenic plants compared to wild-type control plants.

\section{Discussion}

The transformation protocol used in the present study to transform chicory was a modification of the method of Curtis et al. (1994), originally established for the transformation of lettuce. The main differences were the use of leaves and cotyledons from $14 \mathrm{~d}$-old seedlings instead of those from $7 \mathrm{~d}$-old seedlings, and the use of MS liquid medium instead of Uchimiya and Murashige (UM; 1974)-based culture medium for dilution of the Agrobacterium suspensions. Co-cultivation was carried out in the dark and was performed on MS-based regeneration medium and not on UM medium. Additionally, 1 $\mathrm{mg}^{-1} \mathrm{BAP}$ and $0.1 \mathrm{mg} \mathrm{l}^{-1}$ IAA were used instead of $0.5 \mathrm{mg} \mathrm{l}^{-1} \mathrm{BAP}$ and $0.04 \mathrm{mg} \mathrm{l}^{-1} \mathrm{NAA}$ as growth regulators. In contrast to the results reported by Abid et al. (2001), there was no requirement for the addition of acetosyringone to achieve reliable transformation of chicory.

PCR assay for $\Delta^{9}, \Delta^{8}, \Delta^{5}$ and $\Delta^{9}+\Delta^{8}$ genes showed that the cv. Brussels Witloof was optimal in response to transformation with all the constructs used, with $56 \%$ of selected plants carrying the transgenes, followed by Poncho (50.5\%). In the cvs. Pain du Sucre and Pain di Zucchero, 45\% and $47 \%$, respectively, of the selected plants were transformed. The cv. Sponda da Taglio showed the least response (40\%). Brussels Witloof and Sponda 
Mekky, H. et al. Biosynthesis of VLCPUFAs in chicory

da Taglio were the most responsive to double transformation i.e. transformation with the $\Delta^{9}+\Delta^{8}$ genes followed by either the $\Delta^{5}$ or the PGHS- 1 genes. Double transformed plants showed the addition of each extra transgene, without change in the copy number of the $\Delta^{9}+\Delta^{8}$ genes introduced initially into their genomes. RT-PCR confirmed transgene expression in these PCR-positive plants.

GC analysis confirmed that expression of the $\Delta^{9}$ elongase gene alone by production of eicosadienoic and eicosatrienoic acids was optimal in Poncho, Pan di Zucchero and Sponda da Taglio. However, expression of the $\Delta^{9}$ elongase and $\Delta^{8}$ desaturase genes together, resulting in the production of eicosadienoic, eicosatrienoic, dihomo- $\gamma$-linolenic and eicosatetraenoic acids, was best in Brussels Witloof, Pan di Zucchero and Poncho. Those cvs. that responded to double transformation with the $\Delta^{9}$ elongase $+\Delta^{8}$ desaturase genes followed by the $\Delta^{5}$ desaturase gene, synthesized eicosadienoic, eicosatrienoic, dihomo- $\gamma$-linolenic, eicosatetraenoic, arachidonic and eicosapentaenoic acids. GC analysis of plants transformed with either the $\Delta^{8}$ - or the $\Delta^{5}$-desaturase genes alone failed to show the synthesis of VLCPUFAs, probably due to the absence of the substrates eicosadienoic and eicosatrienoic acids required for their desaturating properties to produce the subsequent fatty acids. This provided a way of confirming the steps of the $\Delta^{8}$ pathway described by Wallis and Browse (1999) for the production of arachidonic and eicosapentaenoic acids. Moreover, GC analyses showed that if plants were transformed with the 3 genes on the same vector $\left(\Delta^{9}+\Delta^{8}+\Delta^{5}\right.$ in pCAMBIA-13-EC- $\left.\Delta^{5}-\Delta^{8}-\Delta^{9}\right)$ and transformants selected using $5 \mathrm{mg} \mathrm{l}^{-1}$ hygromycin, the three genes were silent in the transformed plants. This may have been due to the use of the same promoters for the three transgenes of interest, although some of these promoters were in opposite reading directions. Interestingly, this result was consistent with the work performed by Bhullar et al. (2003) and Robert et al. (2005).

The limited production of achenes, especially in transgenic plants, may have been increased if the plants had been vernalized. In future experiments to evaluate longer-term expression of transgenes in chicory, it may be advantageous to micropropagate the original transgenic plants from stem tip cuttings or leaf explants in order to increase the number of plants for such evaluations.

The biosynthesis of considerable concentrations of the important VLCPUFAs, arachidonic acid $(0.1-3.6 \%)$ and eicosapentaenoic acid (1.0 $7.0 \%$ ), has been achieved through the $\omega 3 \Delta^{8}$ and $\omega 6$ $\Delta^{8}$ desaturation biosynthetic pathways for VLCPUFA production in the edible leafy vegetable, chicory. This was consistent with the work of Qi et al. (2004) with Arabidopsis thaliana. Importantly, the percentage accumulation of C20 VLCPUFAs fatty acids reached $29.6 \mathrm{Mol} \%$ in some chicory plants compared with $20 \mathrm{Mol} \%$ produced in A. thaliana, with arachidonic acid and eicosapentaenoic acid concentrations of 6.6 and 3\%, respectively (Qi et al. 2004). These results confirm that genetic engineering of a biosynthetic pathway is possible, as indicated by other workers (Jimenez et al. 2009; Cheng et al. 2010; Napier and Graham 2010; Petrie et al. 2010), even if that pathway is not normally present in the target plant. In the present investigation, the $\Delta^{8}$ desaturation biosynthetic pathway for VLCPUFAs production was inserted into chicory, a leafy vegetable that is normally consumed raw. Furthermore, the production of the physiologically important prostaglandins was confirmed by EIA in the cv. Brussels Witloof with a mean concentration of $767 \mathrm{pg} 100 \mathrm{mg}^{-1}$ freeze-dried leaf. This is the first report of the production of mammalian prostaglandins in plants.

Acknowledgements.HM acknowledges support from the Egyptian Government for a Higher Degree Studentship.

\section{References}

Abid, M., Huss, B. \& Rambour, S. 2001. Transgenic chicory (Cichorium intybus L.) Biotechnology in Agriculture and Foresty, In Bajaj, Y.P.S. (ed.). Transgenic Crops II. Berlin: Springer-Verlag. p. 913-914.

Ani, T., Koga, M., Tanaka, H., Kinshita, T., Rahman, S. \& Takagi, Y. 2003. Improvement of rice (Oryza sativa L.) seed oil quality through introduction of a soybean microsomal omega-3 fatty acid desaturase gene. Plant Cell 
Vol. 20(2011): 327-340.

Reports 21: 988-992.

Balbaa, S.I., Zaki, A.Y., Abdel-Wahab, S.M., El-Denshaiy, E.S.M. \& Motaz-bellah, M. 1973. Preliminary photochemical and pharmacological investigation of the roots of different varieties of Cichorium intybus. Planta Medica 24: 132-144.

Bhullar, S., Chakravarthy, S., Advani, S., Datta, S., Pental, D., \& Burma, P.K. 2003. Strategies for development of functionally equivalent promoters with minimum sequence homology for transgene expression in plants: cis-Elements in a novel DNA context versus domain swapping. Plant Physiology 132: 988-998.

Bischoff, T.A., Kelley, C.J., Karchesy, Y., Laurantos, M., Phuc, N. \& Arefi, A. 2004. Antimalarial activity of lactucin and lactucopicrin: sesquiterpene lactones isolated from Cichorium intybus L. Journal of Ethpharmacology 95: 455-457.

Browse, J., McCourt, J. \& Somerville, C.R. 1986. Fatty acid composition of leaf lipids determined after combined digestion and fatty acid methyl ester formation from fresh tissue. Analytical Biochemistry 152: 141-145.

Cavin, C., Delannoy, M., Malnoe, A., Debeve, E., Touche, A., Courtoi, D. \& Schilter, B. 2005. Inhibition of the expression and activity of cyclooxygenase-2 by chicory extract. Biochemical and Biophysical Research Communications 327: 742-749.

Cheng, B., Wu, G., Vriten, P., Falk, K., Bauer, J., \& Qui, X. 2010. Towards the production of high levels of eicosapentaenoic acid in transgenic plants: the effects of different host species, genes and promoters. Transgenic Research 19: 221-229.

Christope, N., Boris, H. \& Alexandra, A. 1996. The microbiology of mixed salad containing ingredients raw and cooked without dressing. International Journal of Food Science and Technology 31: 481-487.

Curtis, I.S., Power, J.P., Blackhall, N.W., de Laat, A.M.M. \& Davey, M.R. 1994. Genotype-independent transformation of lettuce using Agrobacterium tumefaciens. Journal of Experimental Botany 45: 1441-1449.

Gilani, A.H., Janbaz, K.H. \& Shah, B.H. 1998. Esculetin prevents liver damage induced by paracetamol and $\mathrm{CCl} 4$. Pharmacological Research 37: 31-35.

Gupta, A.K., Kaur, N., Kaur, M. \& Singh, R. 1993. Potential medicinal and nutritional uses of chicory roots and inulin. Studies in Plant Science 3: 359-365.

Hertog, M.G.L., Hollman, P.C.H. \& Venema, D.P. 1992. Optimization of a quantitative HPLC determination of potentially anticarcinogenic flavonoids in vegetables and fruits. Journal of Agricultural and Food Chemistry 40: 1591-1598.

Jimenez, A.U., Bernal, J.L., Nozal, M.J., Toribio, L. \& Bernal, J. 2009. Profile and relative concentrations of fatty acids in corn and soybean seeds from transgenic and isogenic crops. Journal of Chromatography 1216: 7288-7295.

Malarz, J., Stojakowska, A., Szneler, E. \& Kisiel, W. 2005. Furofuran lignans from a callus culture of Cichorium intybus. Plant Cell Reports 24: 246-249.

Malarz, J., Stojakowska, A., Szneler, E. \& Kisiel, W. 2007. Effect of methyl jasmonate and salicylic acid on sesquiterpene lactone accumulation in hairy roots of Cichorium intybus. Acta Physiologia Plantarum 29: 127-132.

Mares, D., Romaganoli, C., Tosi, B., Anderiotti, E., Chille- mi, G. \& Poli, F. 2005. Chicory extracts from Cichorium intybus L. as potential antifungals. Mycopathologia, 160: 85-92.

Meehye, K. \& Kyung, S.H. 1996. The water soluble extract of chicory reduces glucose uptake from the prefused jejunum in rats. The Journal of Nutrition 126: 2236-2242.

Murashige, T. \& Skoog, F. 1962. A revised medium for rapid growth and bioassays with tobacco tissue cultures. Physiologia Plantarum 15: 473-497.

Napier, J.A. 2006. The production of long chain polyunsaturated fatty acids in transgenic plants: a sustainable source for human health and nutrition. Lipid Technology 16: 103-107.

Napier, J.A. \& Graham, I.A. 2010. Tailoring plant lipid composition: designer oilseeds come of age. Current Opinion in Plant Biology 13: 330-337.

Napier, J.A., Sayanova, O., Qi, B. \& Lazarus, C.M. 2004. Progress toward the production of long-chain polyunsaturated fatty acids in transgenic plants. Lipids 39 : 1067-1075.

Pascual, V.M.J. \& Robledo, A. 1998. Screening for antiinsect activity in Mediterranean plants. Industrial Crops Production 8: 183-94.

Petrie, J.R., Liu, Q., Mackenzie, A.M., Shrestha, P., Mansour, M.P., Robert, S.S., Frampton, D.F., Blackburn, S.I., Nichols, P.D. \& Singh, S.P. 2010a. Isolation and characterization of high-efficiency desaturase and elongases from microalgae for transgenic LC-PUFA production. Marine Biotechnology 12: 430-438.

Petrie, J.R., Mackenzie, A.M., Shrestha, P., Liu, Q., Frampton, D.F., Robert, S.S. \& Singh, S.P. 2010b. Isolation of three novel long-chain polyunsaturated fatty acid delta 9 -elongases and the transgenic assembly of the entire Pavlova salina docosahexaenoic acid pathway in Nicotiana benthamiana. Journal of Phycology 46: 917-925.

Petrovic, J., Stanojkovic, A. \& Curcic, S. 2004. Antibacterial activity of Cichorium intybus. Fitoterapia 75: 737-739.

Qi, B., Beaudoinb, F., Frasera, T., Stobart, A.K., Napier, J.A. \& Lazarus, C.M. 2002. Identification of a cDNA encoding a novel C18-delta 9 polyunsaturated fatty acid-specific elongating activity from the docosahexaenoic acid (DHA)-producing microalga, Isochrysis galbana. FEBS Letters 510: 159-165.

Qi, B., Fraser, T., Mugford, S., Dobson, G., Sayanova, O., Butler, J., Napier, J., Stobart, A. \& Lazarus, C.M. 2004. Production of very long chain polyunsaturated omega-3 and omega- 6 fatty acids in plants. Nature Biotechnology 22: 739-745.

Robert, S.S., Singh, S.P., Zhou, X.R., Petrie, J.R., Blackburn, S.I., Mansour, P.M., Nichols, P.D., Liu, Q. \& Green, A.G. 2005. Metabolic engineering of Arabidopsis to produce nutritionally important DHA in seed oil. Functional Plant Biology 32: 473-479.

Sambrook, J., Fritsch, E.F. \& Maniatis, T. 1989. Molecular Cloning: A Laboratory Manual. 2nd edn. Cold Spring Harbor: Cold Spring Harbor Laboratory Press.

Uchimiya, H. \& Murashige, T. 1974. Evaluation of parameters in the isolation of viable protoplasts from cultured tobacco cells. Plant Physiology 54: 936-944.

Venegas-Caleron, M., Sayanova, O. \& Napier, J.A. 2010. An alternatiove to fish oils: Metabolic engineering of oilseed crops to produce omega-3 long chain polyunsaturated fatty acids. Progress in Lipid Research 49: 108-119. 


\section{AGRICULTURAL AND FOOD SCIENCE}

Mekky, H. et al. Biosynthesis of VLCPUFAs in chicory

Taylor, D.C., Francis, T., Guo, Y.M., Brost, J.M., Katavic, V., Mietkiewska, E., Giblin, E.M., Lozinsky, S. \& Hoffman, T. 2009. Molecular cloning and characterization of a KCS gene from Cardamine graeca and its heterologous expression in Brassica oilseeds to engineer high nervonic acid oils for potential medical and industrial use. Plant Biotechnology Journal 7: 925-938.

Wallis, J.G. \& Browse, J. 1999. The delta 8-desaturase of Euglena: An alternative pathway for synthesis of 20 -carbon polyunsaturated fatty acids. Acta Biochimica et Biophysica 365: 307-316.

Wesołowska, A., Nikiforuk, A., Michalska, K., Kisiel, W. \& Chojnacka, E. 2006. Analgesic and sedative activities of lactucin and some lactucin-like guaianolides in mice. Journal of Ethnopharmacology 107: 254-258.

Xiang, C., Han, P., Lutziger, I., Wang, K. \& Oliver, D.J. 1999. A mini binary vector series for plant transformation. Plant Molecular Biology 40: 711-717. 